\title{
SUPERABSORBENT HYDROGEL FROM EXTRACTED OIL PALM FROND WASTE CELLULOSE USING MICROWAVE IRRADIATION FOR CADMIUM ION REMOVAL FROM AQUEOUS SOLUTION
}

\author{
Nesha Selvakumaran', Azwan Lazim¹, ${ }^{\circledR}$
}

https://doi.org/10.23939/chcht13.04.518

\begin{abstract}
This research report facile approach on dispersion of cellulose fiber extracted from oil palm frond waste in a "green-solution" prepared by using urea and sodium hydroxide while the polymerization is carried out using microwave to form hydrogels. Effects of adding cellulose was determined by comparing the swelling degree between $0 \%$ and $2 \%$ cellulose hydrogel. Results showed that swelling ratio enhanced by the presence of cellulose. SEM images exposed that hydrogel with cellulose has rough surface compared to the hydrogels without cellulose. The XRD demonstrated that cellulose hydrogel lost its crystallinity upon polymerization. The DSC analysis showed that upon polymerization the hydrogel has better heat stability compared to the raw oil palm frond cellulose fiber. The FTIR shows successful polymerization has occurred between polyacrylamide and cellulose with a reference to band at $1657.99 \mathrm{~cm}^{-1}$, which indicated the $\mathrm{N}-\mathrm{H}$ bond. The capacity of cellulose hydrogel at different ratios to adsorb cadmium as a function of $\mathrm{pH}$ has also been carried out. Results showed that hydrogel made of $2 \%$ cellulose at $\mathrm{pH} 4$ adsorbed the most cadmium. Therefore, this sorbent can potentially be used as $\mathrm{Cd}$ ion remover in aqueous solution.
\end{abstract}

Keywords: oil palm frond, cellulose, hydrogel, microwave, cadmium.

\section{Introduction}

Cadmium has polluted the environment for at least the past 50 years, moving into and throughout aquatic and soil ecosystems. This naturally occurring metal is found in both water and soil or in sediments at low concentrations due to natural processes, namely volcanic eruptions, natural crust erosion and also anthropogenic activities such as mining and smelting [1]. These non-essential life

\footnotetext{
${ }^{1}$ School of Chemical and Food Science, Faculty of Science and Technology,

University Kebangsaan Malaysia, 436000 UKM Bangi, Selangor, Malaysia

凶azwanlazim@ukm.edu.my

(C) Selvakumaran N., Lazim A., 2019
}

forms are commonly toxic even at relatively low concentrations and may cause adverse effects due to their high bioaccumulation tendency [2]. The International Agency for Research on Cancer (1993) classified cadmium as carcinogenic and teratogenic substance with probable mutagenic properties. Direct exposure to cadmium has been recognised as an urgent public health issue especially in many developing countries as it can cause detrimental effects on the kidneys and bones [3]. Amongst the worst case recorded was itai-itai disease (epidemic bone disease) reported in the late 1960's, that occurred in Japan due to the Cd contamination [4]. Another worrying consequence of cadmium exposure is the risk of developing acute cardiovascular disease [5].

There are various common and conventional analytical instruments or techniques used for $\mathrm{CD}$ detection of cadmium in water or food samples such as voltammetry, inductively couple plasma optic emission spectrometry (ICP-OES), inductively couple plasma mass spectrometry (ICP-MS), and atomic absorption spectrometry (ICP-MS) [6]. Other typical methods used to remove heavy metals from effluents include chemical precipitation, electrolysis, membrane separation, ion exchange, and absorption by activated carbon [7]. Most of these methods suffer from a combination of high capital, high operational cost and disposal of resulting sludge or any of those drawbacks [8]. Hence, researches have focused on investigating low-cost materials such as agricultural byproducts, industrial wastes and biological materials as adsorbents to remove heavy metals from industrial wastewater. Usually, these wastes are further functioning by introducing new functional groups to improve their performance as adsorbent. As example, apple waste, sawdust and rice husk were modified to perform as biosorbent $[9,10]$.

Oil palm biomasses are produced in large quantity in Malaysia as the palm oil industry is among the major contributors of the agro-industry. The leftover mainly consists of cellulose and hemicellulose with the former constituting one of the most abundant natural polymers on earth [11]. Oil palm frond (OPF) is one of the hugely 
produced biomasses at oil palm plantations. It was reported that approximately 50 million tons of OPF were produced per annum in Malaysia, which are available throughout the year as the fronds are frequently cut during the harvesting of fresh fruit bunches. The fibers of cellulose are soft thus making it easy to be processed. The structure is built by a number of glucose units that are linked by $\beta$ (1-4) glycosidic linkage in a long chain and have a very strong affinity. The hydrogen bonding through van der Waals forces makes this structure very stable and insoluble not only in water but also in the majority of organic and inorganic solvents. Per previous reports, fibers/cellulose extracted from different parts of oil palm tree was successfully performed in removing heavy metal from waste water [12].

Hydrogels are 3-D cross-linked polymer networks that have gained marked attention for their wide applications in drug delivery, tissue engineering, removal of metal ions and dyes [13]. Having a three-dimensional network structure, hydrogels are able to absorb and retain water without losing their network structure [14]. Moreover, this material is easy to tailor accordingly to the purpose and its end use. Apart from that, it is also an intelligent material that elegantly maintains its unique physical characteristics such as tissue-like elasticity and mechanical strength even after swelling in aqueous medium [15]. However, forming hydrogels by incorporating natural polysaccharides have improved its properties significantly. For example, grafting of vinyl monomers onto natural polysaccharides results in finetuned products for industrial applications [16]. Since the hydrogel continuously gains demand from the industry, microwave irradiation is emerging as an efficient source of thermal energy and constitutes a very original procedure of heating materials which are different from the classical approach that was commonly used to prepare hydrogel. The application of microwave irradiation as the source of thermal energy lies in its effectivity due to the small amount of time that is needed for it [17].

The objective of this study is to prepare hydrogel from oil palm frond cellulose incorporated with polyacrylamide. The cadmium adsorption capacity of this bio-composite was evaluated as a function of $\mathrm{pH}$. The hydrogel was prepared by using simple one-pot step using microwave heating. The morphology, chemical, thermal and swelling properties of the hydrogels was investigated and subjected to a systematic cadmium absorption study.

\section{Experimental}

\subsection{Materials}

Oil palm frond (OPF) cellulose was obtained from University Putra Malaysia. Urea (Systerm), sodium hydroxide $(\mathrm{NaOH})$ (Systerm), polyacrylamide (Sigma Aldrich), $N, N$ '-methylenebisacrylamide (MBA) (Merck 8), potassium persulfate (KPS) (Merck 8), nitric acid $\left(\mathrm{HNO}_{3}\right)$ (Systerm) and cadmium sulpahate $\left(3 \mathrm{CdSO}_{4} \cdot 8 \mathrm{H}_{2} \mathrm{O}\right)$ (AnalaR) were used. The stock solution containing $1000 \mathrm{mg} / \mathrm{l}$ of $\mathrm{Cd}(\mathrm{II})$ was prepared by dissolving a known quantity of cadmium sulphate in $1000 \mathrm{ml}$ of distilled water. This stock solution was diluted as required to obtain a series of working solutions. The solution $\mathrm{pH}$ was adjusted by adding $0.1 \mathrm{~mol} / 1$ of $\mathrm{HNO}_{3}$ or $\mathrm{NaOH}$ solution. All chemicals used were of analytical reagent grade, and all solutions were prepared with distilled water unless stated otherwise.

\subsection{Dissolution of Cellulose}

OPF cellulose was dispersed in urea $/ \mathrm{NaOH}$ solution. The ratio of urea to $\mathrm{NaOH}$ to distilled water prepared is 7:12:81. The solution was pre-cooled at $268 \mathrm{~K}$ prior to dissolving the cellulose [18]. A calculated amount that corresponded to $2 \%(\mathrm{w} / \mathrm{v})$ of cellulose fiber was added to the solution and shaken vigorously by hand, since according to the literature this dissolution is regarded as the most optimum one, since with the increases of cellulose concentration in the hydrogel more $-\mathrm{COOH}$ groups become available for the absorption of cadmium ions. Amount of optimum cellulose fiber was fixed at $2 \%$ according to the preliminary studies conducted using different concentration of cellulose fiber.

\subsection{Preparation of Hydrogel}

Cellulose hydrogel was prepared by mixing $4 \mathrm{~g}$ of polyacrylamide, $0.2 \mathrm{~g}$ of $N, N^{\prime}$-methylenebisacrylamide (MBA) as a cross-linker and $15 \mathrm{ml}$ of the dispersed $2 \%$ cellulose solution. $0.2 \mathrm{~g}$ of potassium persulfate was used as the initiator and graft copolymerization was carried out [19]. The solution was casted on Petri dish and polymerization was initiated by using a microwave at $100 \mathrm{~W}$ for $2 \mathrm{~min}$. The hydrogel was then washed with plenty of distilled water and dried in oven at $313 \mathrm{~K}$ overnight. Zero hydrogel was prepared by using the same method but without adding dispersed cellulose solution. Once dried, the hydrogels were peeled off the petri dish and cut into small pieces weighing $50 \mathrm{mg}$ each [20].

\subsection{Swelling Index Hydrogel}

About $50 \mathrm{mg}$ of hydrogel was weighed and left in $25 \mathrm{ml}$ of distilled water overnight. It was then filtered using filter funnel and filter paper was used to remove any excessive water. Moreover, the swelling behavior of the hydrogel was assessed by using the swelling ratio, which is expressed by the ratio of swollen sample weight over the weight of the dry sample and the weight of the 
hydrogel was measured after swelling [21]. Each test was carried out in triplicate. The formula used to calculate the swelling index of the hydrogel is:

$$
S_{e q}=\frac{M-M_{0}}{M_{0}} \cdot 100
$$

where $M$ and $M_{0}(\mathrm{~g})$ is the mass of swollen and dried hydrogels, respectively, $g$ [22].

\subsection{Adsorption Experiments}

Adsorption experiments were performed in a series of $50 \mathrm{ml}$ conical flasks containing $50 \mathrm{mg}$ of hydrogel and $25 \mathrm{mд}$ of $2 \mathrm{ppm} \mathrm{Cd}(\mathrm{II})$ solution. The adsorbents were then separated by direct filtration after a given time. The concentration of $\mathrm{Cd}(\mathrm{II})$ in the solution was measured by using atomic absorption spectrometry (AAS). To study the effects of $\mathrm{pH}$ on the adsorption capacity, the adsorption experiments were performed at five $\mathrm{pH}$ values: $2,3,4,5$, and 6 with an initial concentration of $2 \mathrm{mg} / \mathrm{l}$ and the contact time of $120 \mathrm{~min}$ [23]. The term contact time is defined as to describe the time of adhesion between an adhesive and a surface, before performing further measurements. The adsorption capacity of the hydrogel was calculated using Eq. (2):

$$
q_{e}=\frac{\left(C_{0}-C_{e}\right) \cdot V}{m}
$$

where $q_{e}$ is the adsorption capacity, $\mathrm{mg} / \mathrm{g} ; C_{0}$ and $C_{e}$ are the initial and equilibrium concentrations, $\mathrm{mg} / \mathrm{l} ; m$ is the mass of the adsorbent used, mg; $V$ is the volume of the solution used, $\mathrm{ml}[24]$.

\subsection{Characterization}

FTIR-ATR was used to detect the chemical bonds and functional groups of the hydrogel. Spectrums were collected for each of the samples within the wavenumber range of $650-400 \mathrm{~cm}^{-1}$. The surface morphology of the hydrogels was examined by SEM. The samples were coated with a thin gold layer (two times, $40 \mathrm{Ma}, 60 \mathrm{~s}^{-1}$, approx. $30 \mathrm{~nm}$ ) by a sputter coater unit (BALZER SCD 050 Sputter Coater, BAL-TEC) and surface topography was analyzed using JEOL JSM 6300F SEM operated at an acceleration voltage of $5 \mathrm{kV}$. The X-ray diffraction pat- terns (XRD) of the hydrogels were recorded with oriented mounts using Philips X'Pert Pro X-ray diffractometer. The radiation used was $45 \mathrm{kV}$ and $40 \mathrm{~mA}$ for two ranges of 0 $60^{\circ}$. In order to investigate the thermal properties of starch, polyacrylamide, and synthesized hydrogels, differential scanning calorimetry (DSC) analysis of the samples were carried out with Perkin-Elmer Diamond TG/DSC Analyzer. The analyses were made using aluminum pans under a dynamic nitrogen atmosphere in the temperature range of $253-73 \mathrm{~K}$ and the heating rate of $10 \mathrm{~K} / \mathrm{min}$.

\section{Results and Discussion}

\subsection{Synthesis of Grafted Cellulose- Polyacrylamide Hydrogel (C-g-pAam)}

Scheme 1 shows the homogeneous modification of cellulose with acrylamide in $\mathrm{NaOH} /$ urea aqueous solution. The mechanism proposed that only low concentration of potassium persulfate is needed to promote acrylamide grafted efficiently onto OPF cellulose under microwave irradiation. The reaction is highly associated with the hydroxyl group of cellulose in combination with $\mathrm{NaOH} /$ urea. The heat produced consequently became reactive and accessible to interact with media such as acrylamide. The significant increase in reaction rates for both organic and inorganic reactions undergone a microwave irradiation is observed [25]. In comparison with conventional procedures, oxygen becomes a very potent inhibitor for most common vinyl monomers because it combines with active free radicals to give relatively inactive ones which are capable of propagating the chain reaction. To overcome this, the reaction media are usually thoroughly purged with inert gas to eliminate the existence of $\mathrm{O}_{2}$ or otherwise the reaction may not occur. Unlikely, under microwave conditions, the presence of $\mathrm{O}_{2}$ does not affect the normal graft co-polymerization reaction. It is assumed that under the influence of microwaves the oxygen reversibly combines with the primary free radicals and thus the oxygen is unable to inhibit the chain propagation and polymerization.

$$
\text { Cellulose-OH }+\mathrm{nCH}_{2}=\underset{\mathrm{CONH}_{2}}{\mathrm{CH}} \stackrel{100 \mathrm{~W} \text { microwave power }}{\mathrm{K}_{2} \mathrm{~S}_{2} \mathrm{O}_{8} ; 60 \mathrm{~s}} \underset{\mathrm{CONH}_{2}}{\mathrm{CONH}_{2}}
$$

Acrylamide Cellulose-graft-poly(acrylamide)

Scheme 1. Proposed mechanism for the synthesis of OPF cellulose grafted polyacrylamide using microwave 


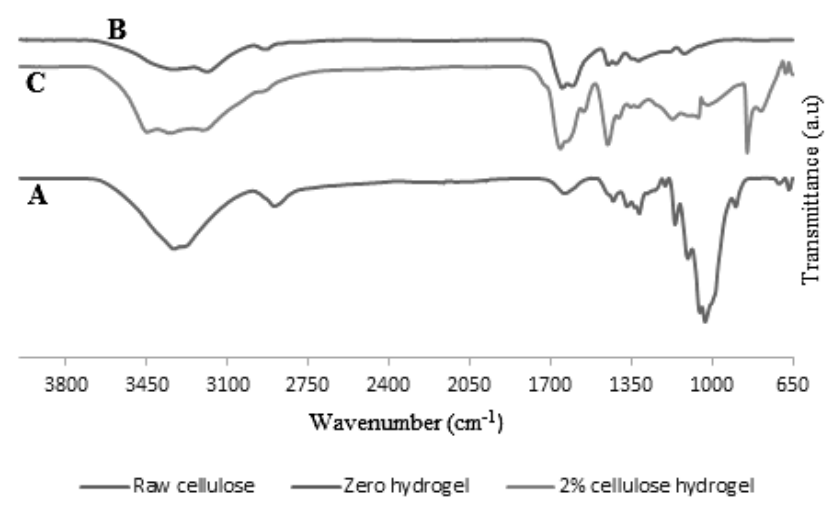

Fig. 1. The FTIR spectra of raw cellulose (A), zero hydrogel (B) and $2 \%$ cellulose hydrogel (C)

\subsection{Fourier Transformed Infrared (FTIR)}

The FTIR spectra of raw cellulose, zero hydrogel and cellulose hydrogel is shown in Fig. 1.

The absorption peak observed at $3334 \mathrm{~cm}^{-1}$ is related to the $\mathrm{O}-\mathrm{H}$ stretching vibration of hydroxyl group. The peak observed at $2900 \mathrm{~cm}^{-1}$ corresponds to $\mathrm{CH}_{2}$ groups. Absence of peaks located in the range of 1509 $1609 \mathrm{~cm}^{-1}$ corresponds to $\mathrm{C}=\mathrm{C}$ aromatic skeletal vibrations, which indicates the complete removal of lignin. The absorption band that corresponds to either acetyl or uronic ester groups of hemicellulose and normally appears in the region of $1700-1740 \mathrm{~cm}^{-1}$ was absent. This indicates the removal of hemicellulose during acid hydrolysis. The two bands around 1060 and $895 \mathrm{~cm}^{-1}$ are associated with $\mathrm{C}-\mathrm{O}$ stretching and $\mathrm{C}-\mathrm{H}$ rocking vibrations of the carbohydrates, respectively [26].

The zero hydrogel band observed at 3350 and $3189 \mathrm{~cm}^{-1}$ is the primary N-H stretch of polyacrylamide. The band at $1648 \mathrm{~cm}^{-1}$ corresponds to $\mathrm{N}-\mathrm{H}$ bending while the band at $1120 \mathrm{~cm}^{-1}$ - to the $\mathrm{C}-\mathrm{N}$ stretch of the polyacrylamide. As for the cellulose hydrogel, the broad band at $3342 \mathrm{~cm}^{-1}$ is characteristic of $\mathrm{O}-\mathrm{H}$ vibration that is unique to cellulose. The band at $1658 \mathrm{~cm}^{-1}$ indicates the $\mathrm{N}-\mathrm{H}$ bond in acrylamide. This band confirms the polymerization between cellulose and acrylamide. Meanwhile, the band at $1452 \mathrm{~cm}^{-1}$ confirms the stretching vibration of $\mathrm{C}-\mathrm{OH}$ while the band observed at $847 \mathrm{~cm}^{-1}$ is the $\mathrm{C}-\mathrm{O}$ vibration of epoxy group. In addition, the absorption at $\sim 1645 \mathrm{~cm}^{-1}$ in all samples is indicative of the water molecule absorption due to strong interaction between cellulose and water. The broad peaks within $3382-3353 \mathrm{~cm}^{-1}$ constitute a further confirmation of the existence of carboxylic O-H groups $\left(2500-3500 \mathrm{~cm}^{-1}\right)$. Therefore, based on the porous structure and the irregular surface along with high amounts of introduced free carboxyl groups, it can be concluded that the hydrogel presents an adequate physical and chemical characteristic to adsorb metals.

\subsection{Scanning Electron Emission (SEM)}

The SEM results for raw cellulose fiber, zero hydrogel and $2 \%$ cellulose hydrogel are shown in Fig. 2. Raw cellulose fibers are made of rigid, highly ordered fibrils (Fig. 2a). There were no particles and the surface morphology was flat with a very clear and smooth outer for zero hydrogel sample (Fig. 2b). On the contrary, the $2 \%$ cellulose hydrogel (Fig. 2c) has spherical rod particles of cellulose homogenously dispersed on the surface [27]. This image verifies that the cellulose hydrogel has porous structure, which is important from the viewpoint of its application in different fields. In general, water permeation, as well as the interaction of external stimuli with polymers hydrophilic groups occur in these pores. The porous architecture could be also loaded with inorganic compounds or any material. Therefore, the porous structure is the predominant reason for the cellulose hydrogel high swelling capacity rate [28].

\subsection{Thermal Analysis of Cellulose and Hydrogel}

DSC is an excellent technique to assess the miscibility of the components within a hydrogel network and to prove the existence of intermolecular interactions between the components. The thermograms of raw cellulose fibers, zero hydrogels and $2 \%$ cellulose hydrogels are presented in Fig. 3. From the DSC analysis, it can be observed that the heat of decomposition and the crystallinity index have same trend which is attributed to the occurrence of heterolytic thermolysis of glycosidic bonds along the ordered chains. It was also observed that the temperature onset $\left(T_{i}\right)$, melting temperature $\left(T_{m}\right)$ and the enthalpy of heating $(\Delta H)$ for hydrogel was higher than those values for OPF cellulose. Higher onset temperatures are often associated with higher thermal stability. In Fig. 3a, raw cellulose exhibits sharp endothermic peak at $336.01 \mathrm{~K}$. Meanwhile, zero hydrogel (Fig. 3b) exhibits a sharp peak at $367.01 \mathrm{~K}$. The cross-linking between polyacrylamide and cellulose increases the endothermic peak of $2 \%$ cellulose hydrogel (Fig. 3c) to $374.95 \mathrm{~K}$ and the maximum temperature shifted to higher temperature. Cellulose hydrogel also denatures at temperature above $433.00 \mathrm{~K}$, which means that it is thermally stable in the aforementioned temperatures used [29].

\subsection{X-Ray Diffraction (XRD)}

The X-ray diffractograms of raw cellulose fiber and hydrogels are shown in Fig. 4. It is widely known that cellulose contains both crystalline and amorphous region. Diffraction peak measured at $22.5^{\circ}$ is sharp, indicating high crystallinity of the raw cellulose fiber (Fig. 4a). It is 
believed that improving the cellulose crystallinity increases their rigidity, which leads to the increase in mechanical properties of cellulose. Both intra- and intermolecular hydrogen bonding occur in cellulose via hydroxyl groups, which results in various crystalline arrangements in an orderly fashion. The X-ray diffractograms show that the majority of the peak intensity is located at $2 \theta$ value of around $22.6^{\circ}$, which is related to the crystalline structure of cellulose for all samples, whilst the amorphous background is characterized by the low diffracted intensity at a $2 \theta$ value of around $16^{\circ}$. Meanwhile, the absence of a sharp crystalline peak in the XRD plots of hydrogels (Fig. 4b) suggests that they are mainly amorphous in nature. Grafting is further confirmed by comparison of the XRD of cellulose-graft-poly(acrylamide) (Fig. 4c) with those of raw OPF cellulose fiber, while cellulose-graft-poly(acrylamide) shows halos typical for amorphous polymers. It has been also observed that the crystallinity is lost upon grafting [30].

\subsection{Swelling Properties of Hydrogel}

In previous sections, the surface morphology and hydrogel porosity has been discussed. A noticeable property of the hydrogel is its ability to swell in aqueous media without dissolving in it. Swelling occurs due to the elastic stretching of the polymer chain fragments between cross-linking points. Stretching of chain fragments increases the elastic retractive force of the entropic origin, which in turn counteracts the network expansion. The balance of these two opposing contributions is governed by the equilibrium volume of the polymer network. The hydrogel swelling is a consequence of the balance between cohesive and dispersive forces on the hydrated polymer chains. Through the swelling test, it has been found that zero hydrogel has a swelling index of $15 \%$, while the $2 \%$ cellulose hydrogel has a swelling index of $1814 \%$. The swelling index corresponds to the fractional increase of a hydrogel weight, due to the absorption of water [31]. The swelling of hydrogel increased tremendously with the addition of cellulose fiber. It is noted that high swelling ratio is related to the formation of vastly porous structure that consequently increases the transparency of hydrogels. According to Flory-HugginsTanaka theory, the swelling ability of hydrogels is controlled by the amount of carboxyl group. High equilibrium swelling ratio indicates that the samples are superabsorbent hydrogels. It is important for biodegradable materials to have high swelling ratio for wide application in the industry. Examples of such applications include biomedicine (contact lenses, tissue engineering scaffolds, wound dressings), hygienic products, and agriculture [32]. Without the addition of cellulose fiber, the hydrogel is very stiff and thus not flexible as zero hydrogel does not absorb much water when immersed in it. But with the addition of cellulose fiber, the hydrogel becomes soft and flexible. This improvement in the swelling capacity of the hydrogel is attributed to the presence of cellulose with different morphology and surface charges. Besides, cellulose in the hydrogel can expand the hydrogel network and increase the pores and free spaces within this network to enable water absorption. In the present work, the prepared hydrogel contained hydrophilic functional groups such as $-\mathrm{COOH}$, that are ionisable in aqueous media and can therefore be used for absorption of pollutants such as heavy metals from contaminated water.

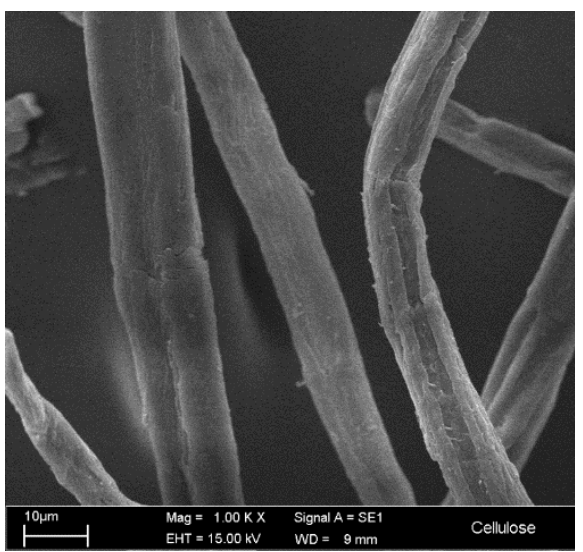

a)

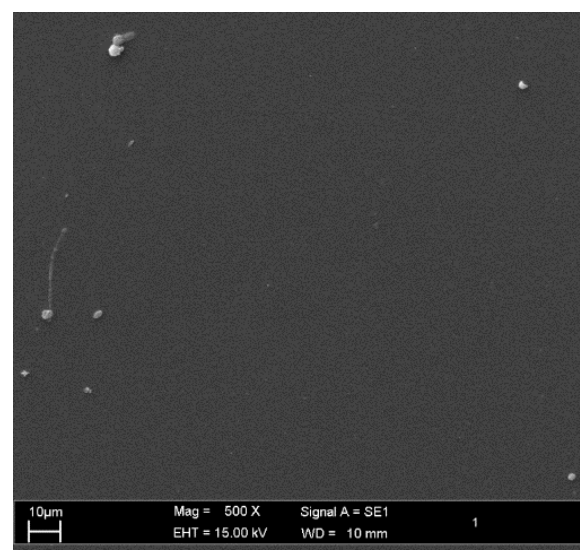

b)

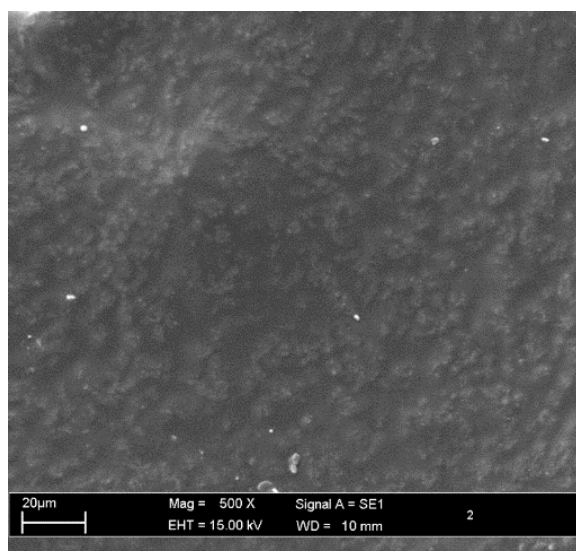

c)

Fig. 2. SEM micrographs of raw cellulose fiber (a), zero hydrogel (b) and $2 \%$ cellulose hydrogel (c) 


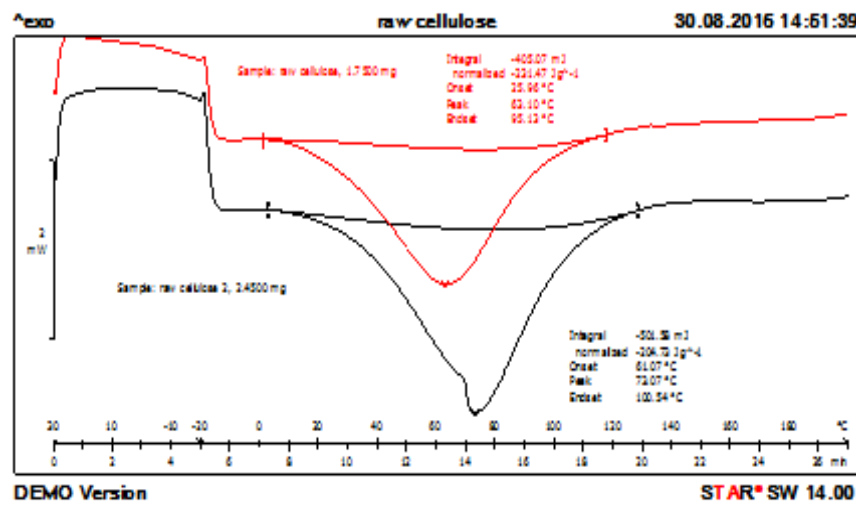

a)

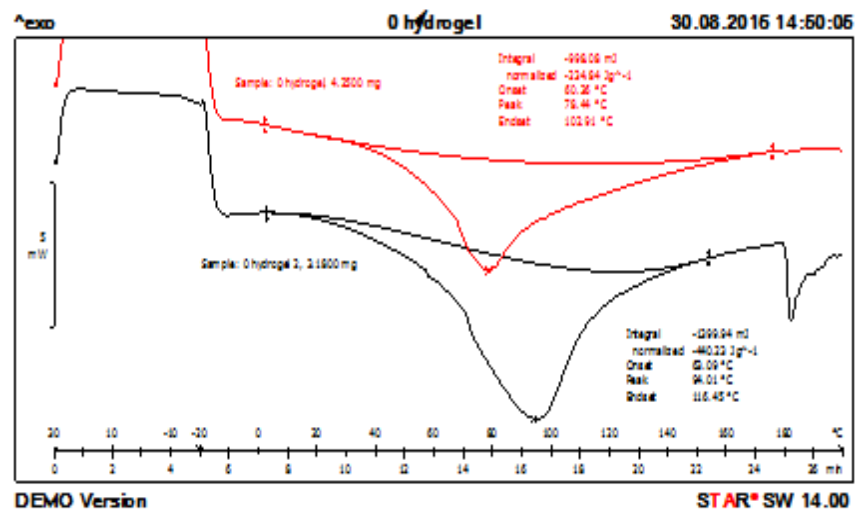

b)

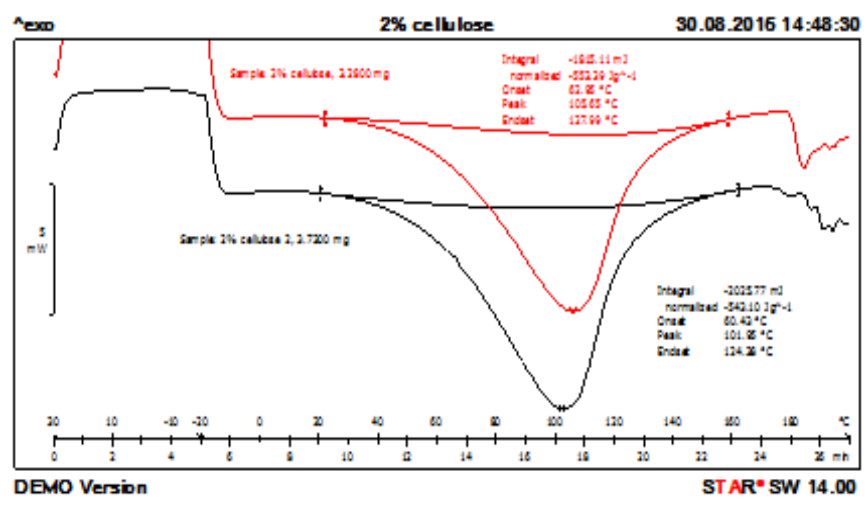

c)

Fig. 3. DSC thermograms of raw cellulose fiber (a), zero hydrogel (b) and $2 \%$ cellulose hydrogel (c)

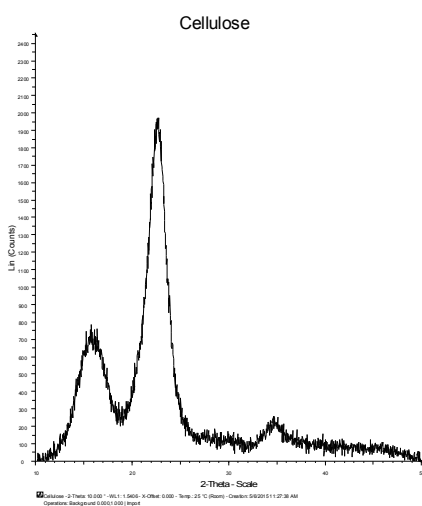

a)

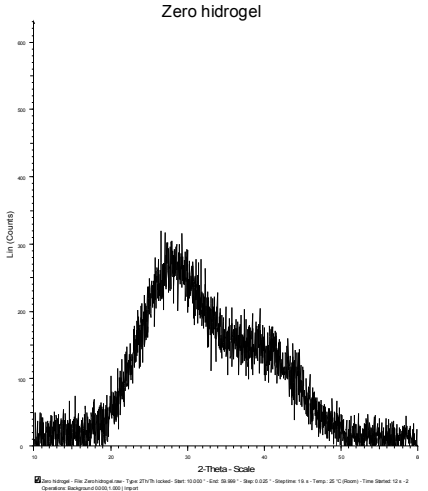

b)

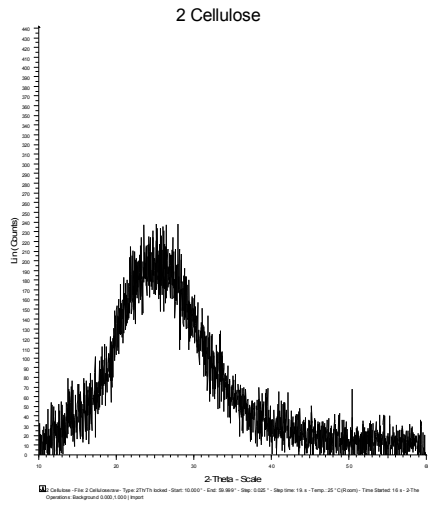

c)

Fig. 4. X-ray diffractograms of raw cellulose fiber (a), zero hydrogel (b) and $2 \%$ cellulose hydrogel (c) 


\subsection{Application}

Absorption studies were performed in $100 \mathrm{ml}$ conical flask at ambient temperature. Cadmium concentration was determined at the end of each experiment with AAS by diluting the solution accordingly.

\subsubsection{Effect of cellulose concentration on cadmium absorption}

Fig. 5 shows the effects of cellulose concentration in hydrogel on cadmium adsorption. The results show that as the concentration of cellulose increases in the hydrogel, the adsorption of cadmium increases as well. The optimum concentration of cellulose for cadmium adsorption is $2 \%$ of dissolved cellulose. As the concentration of cellulose increases in the hydrogel, more $-\mathrm{COOH}$ groups become available for the absorption of cadmium ions. It also increases the flexibility of the hydrogel to absorb more water and increase the swelling [33]. However, when the concentration of cellulose is higher than $2 \%$, the hydrogel becomes too rigid and tough, which causes the loss of hydrogel ability to absorb more water and decreases its swelling ability. Hence, it can be concluded that the cadmium absorption of the hydrogel decreases when the concentration of cellulose is more than $2 \%$.

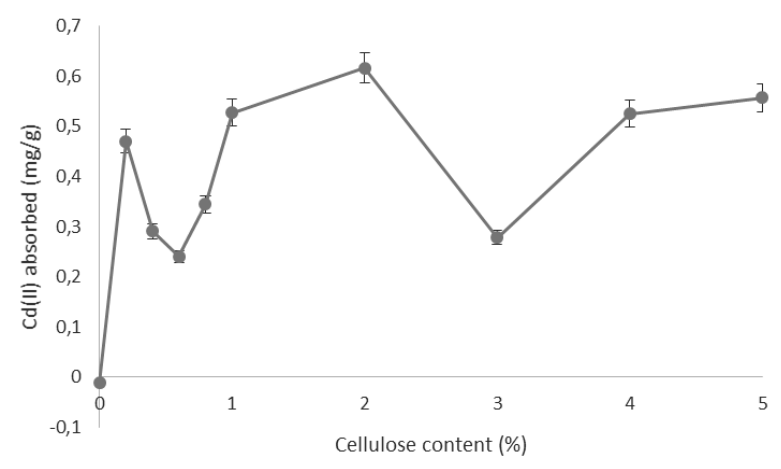

Fig. 5. Effect of cellulose content in hydrogel on $\mathrm{Cd}(\mathrm{II})$ absorption

\subsubsection{Effect of $\mathrm{pH}$ on swelling behavior}

Generally, the $\mathrm{pH}$ value is one of the most important parameters affecting the adsorption process. Hydrogels containing one or more electron donor atoms (Lewis base) such as $\mathrm{N}, \mathrm{S}, \mathrm{O}$, and $\mathrm{P}$ form coordinate bonds with most of the toxic metal ions (Lewis acid) [34]. In this study, the binding properties of cellulose hydrogel for $\mathrm{Cd}^{2+}$ metal ions were tested under non-competitive conditions by immersing a sample in a solution containing metal ions. In order to investigate the influence of different $\mathrm{pH}$ values on cadmium adsorption, zero hydrogel and $2 \%$ cellulose hydrogel were studied at various $\mathrm{pHs}$ ranged from $\mathrm{pH} 2$ to $\mathrm{pH} 6$. The $\mathrm{pH}$ dependence of $q_{e}$ for the $\mathrm{Cd}^{2+}$ is shown in Fig. 6. The increase in adsorption corresponds with the increase in the $\mathrm{pH}_{0}$ of the solution in the range of 2.0-6.0. At $\mathrm{pH}_{0}>4$, the $q_{e}$ values decrease [35]. $\mathrm{pH}_{0}=4$ was found to be an optimum for $\mathrm{Cd}^{2+}$ adsorption on $2 \%$ cellulose hydrogel. The value of $\mathrm{pH}$ plays a vital role in adsorption of $\mathrm{Cd}(\mathrm{II})$ ion because hydrogen ions in the solution compete with the positive charge interacted with the negative charge on active sites of the adsorbent. The study has showed that the system is strongly $\mathrm{pH}$ dependent. To our best knowledge, this behavior can be explained in these three steps. Firstly, at a low $\mathrm{pH}$ value, the positively charged ions occur in a higher density due to the increase of adsorbed protons on the surface resulting in lower efficiency. Secondly, with an increasing $\mathrm{pH}$ value, the electrostatic repulsion decreases because of the reduction of positive charge density on adsorption sites, which in turn results in an increase in the adsorption of metal ions. Finally, at the higher $\mathrm{pH}$ value $(\mathrm{pH} \geq 5)$ that has been optimized, the $\mathrm{OH}^{-}$ions completely react with metal ions at the active sites on the adsorbent surfaces, which results in a decrease in the adsorption capacity. In this study, $\mathrm{Cd}^{2+}$ adsorption onto the surface of these hydrogels is assumed to occur through ion-exchange and chelation between positively charged $\mathrm{Cd}^{2+}$ and nonionized or ionized carboxylic groups within the polymer hydrogels.

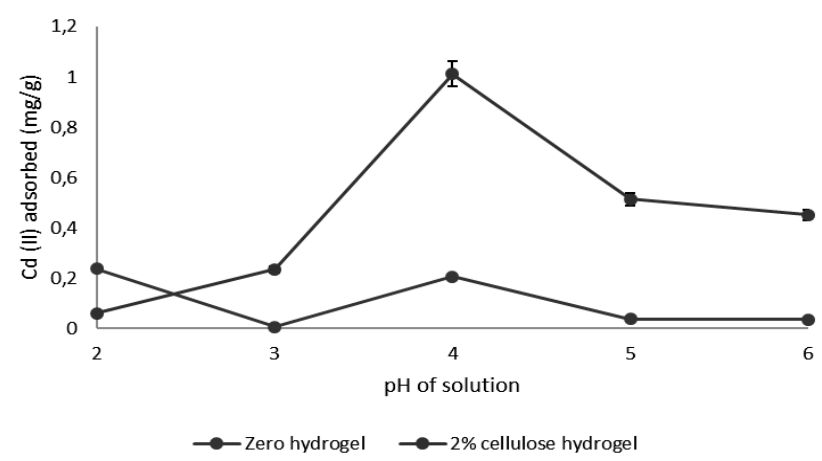

Fig. 6. Cd(II) absorption by different hydrogel samples (with $2 \%$ cellulose and without cellulose) as a function of $\mathrm{pH}$

\section{Conclusions}

Cellulose grafted polyacrylamide (C-g-pAam) hydrogels were synthesized using $N, N^{\prime}$-methylenebisacrylamide as a cross-linking agent and their effiency to absorb cadmium in water sample was investigated. From the experiments performed we can conclude that adding OPF cellulose fiber will increase the swelling index of the hydrogel and its flexibility, which are very important characteristics of hydrogels. It was also found that cadmium absorption of $2 \%$ cellulose hydrogel is 
$56.84 \%$ at $\mathrm{pH} 4$, demonstrating that the system we used is $\mathrm{pH}$ dependent.

\section{Acknowledgements}

This work was financially supported in part by research grants given by University Kebangsaan Malaysia (GUP-2016-012/LIV-2015-05) and Ministry of Education.

\section{References}

[1] Caló E., Khutoryanskiy V.: Eur. Polym. J., 2015, 65, 252. https://doi.org/10.1016/j.eurpolymj.2014.11.024

[2] Liu X., Zhong L., Meng J. et al.: Environ. Pollut., 2018, 239, 308. https://doi.org/10.1016/i.envpol.2018.04.033

[3] Fan R., Hu P., Wang Y. et al.: Toxic. Lett., 2018, 299, 56. https://doi.org/10.1016/j.toxlet.2018.09.003

[4] Nogawa K., Suwazono Y., Nishijo M. et al.: Environ. Res., 2018, 164, 379. https://doi.org/10.1016/j.envres.2018.03.019

「51 Tinkov A., Filippini T., Ajsuvakavo O. et al.: Sci. Total Environ., 2017, 601-602, 741. https://doi.org/10.1016/j.scitotenv.2017.05.224 [6] Cervantes A., Rodriguez R., Ferrer L. et al.: Microchem. J., 2017, 132, 107. https://doi.org/10.1016/j.microc.2017.01.016 [7] Kurchatov I., Laguntsov N., Neschimento Y., Feklistov D.: Phys. Procedia, 2015, 72, 89.

https://doi.org/10.1016/j.phpro.2015.09.025

[8] Gitis V., Hankins N.: J. Water Proc. Eng., 2018, 25, 34.

https://doi.org/10.1016/j.jwpe.2018.06.003

[9] Nguyen T., Ngo H., Guo W. et al.: Biores. Technol., 2013, 148,

574. https://doi.org/10.1016/j.biortech.2013.08.124

[10] Tovar-Carrillo K., Nakasone K., Sugita S. et al.: Mater. Sci.

Eng. C, 2014, 42, 808. https://doi.org/10.1016/j.msec.2014.06.023

[11] Loh S.: Energ. Convers. Manage., 2017, 141, 285.

https://doi.org/10.1016/j.enconman.2016.08.081

[12] Rahmi, Lelifajri, Julinawati, Shabrina: Carbohydr. Polym.,

2017, 170, 226. https://doi.org/10.1016/j.carbpol.2017.04.084

[13] Rui-Hong X., Peng-Gang R., Jian H. et al.: Carbohyd. Polym., 2016, 138, 222. https://doi.org/10.1016/j.carbpol.2015.11.042

[14] Soares P., De Seixas J., Albuquerque P. et al.: Carbohyd.

Polym., 2015, 134, 673.

https://doi.org/10.1016/j.carbpol.2015.08.042

[15] Perez R., Won J., Knowles J., Kim H.: Adv. Drug Deliv. Rev., 2013, 65, 471. https://doi.org/10.1016/j.addr.2012.03.009

[16] Sharma R., Kumar R., Singh A.: Separ. Purif. Technol., 2019, 209, 684. https://doi.org/10.1016/j.seppur.2018.09.011

[17] Bardajee G., Azimi S., Sharifi M.: Microchem. J., 2017, 133, 358. https://doi.org/10.1016/j.microc.2017.03.037

[18] Kojima Y., Takayasu M., Toma M., Koda S.: Ultrasonic.

Sonochem., 2019, 51, 419.

https://doi.org/10.1016/j.ultsonch.2018.07.030

[19] Maitra J., Shukla V.: Am. J. Polym. Sci., 2014, 4, 25.

https://doi.org/10.5923/j.ajps.20140402.01

[20] Ahmed E.: J. Adv. Res., 2015, 6: 105.

https://doi.org/10.1016/j.jare.2013.07.006

[21] Sun X., Zhao X., Zhao L. et al.: J. Mater. Chem. B, 2015, 3, 6368. https://doi.org/10.1039/C5TB00645G

[22] Selvakumaran N., Lazim M.: AIP Conf. Proc., 2016, 1784, 030018. https://doi.org/10.1063/1.4966756

[23] Robles J., Peresin M., Tamminen T. et al.: Int. J. Biol.

Macromol., 2018, 115, 1249.

https://doi.org/10.1016/j.ijbiomac.2018.04.044
[24] Li X., Wang S., Liu Y. et al.: J. Chem. Eng. Data, 2017, 62, 407. https://doi.org/10.1021/acs.jced.6b00746

[25] Hu X., Wang Y., Xu M. et al.: Polym. Test., 2018, 71, 344. https://doi.org/10.1016/j.polymertesting.2018.09.027

[26] Ilyas R., Sapuan S., Ishak M.: Carbohyd. Polym., 2018, 181, 1038. https://doi.org/10.1016/j.carbpol.2017.11.045

$\lceil 27\rceil$ Isobe N., Komamiya T., Kimura S. et al.: Int. J. Biol.

Macromol., 2018, 117, 625.

https://doi.org/10.1016/j.ijbiomac.2018.05.071

[28] Hu W., Zhang P., Liu X. et al.: Chem. Eng. J., 2018, 353, 708.

https://doi.org/10.1016/j.cej.2018.07.147

[29] Haafiz M., Eichhorn S., Hassan A., Jawaid M.: Carbohyd.

Polym., 2013, 93, 628.

https://doi.org/10.1016/i.carbpol.2013.01.035

[30] Liang X., Qu B., Li J. et al.: React. Funct. Polym., 2015, 86, 1. https://doi.org/10.1016/j.reactfunctpolym.2014.11.002

[31] Teow Y., Kam L., Mohammad A.: J. Environ. Chem. Eng., 2018, 6, 4588. https://doi.org/10.1016/j.jece.2018.07.010

[32] Abdel-Halim E., Al-Deyab S.: React. Funct. Polym., 2014, 75,

1. https://doi.org/10.1016/.j.reactfunctpolym.2013.12.003

[33] Kim Y., Kim Y.-K., Kim S. et al.: Chem. Eng. J., 2017, 313,

1042. https://doi.org/10.1016/j.cej.2016.10.136

¡34] Omondi B., Okabe H., Hidaka Y., Hara K.: React. Funct.

Polym., 2018, 130, 90.

https://doi.org/10.1016/j.reactfunctpolym.2018.06.006

[35] Pal P., Pal A.: Int. J. Biol. Macromol., 2017, 104, 1548.

https://doi.org/10.1016/j.ijbiomac.2017.02.042

Received: May 26, 2018 / Revised: October 01, 2018 / Accepted: December 12, 2018

СУПЕРАБСОРБУЮЧИЙ ГІДРОГЕЛЬ
3 ЕКСТРАГОВАНОЮ 3 ВДХОДІВ ЛИСТЯ
ОЛІЙНОЇ ПАЛЬМИ ЦЕЛЮЛОЗОЮ 3
ВИКОРИСТАННЯМ МІКРОХВИЛЬОВОГО
ВИПРОМННЮВАННЯ ДЛЯ ВИЛУЧЕННЯ
КАДМИЙЙОНІВ 3 ВОДНОГО РОЗЧИНУ

Анотація. Проведено диспергування целюлозного волокна, екстрагованого з відходів листя олійної пальми в «зеленому розчині», одержаному з сечовини та гідроксиду натрію. Для синтезу гідрогелів застосовано реакиію полімеризаиії з використанням мікрохвилього випромінення. Вплив додавання целюлози визначено внаслідок порівняння ступеня набухання гідрогелю з $0 \%$ i $2 \%$ иелюлози. Показано, щзо коефіцієнт набухання збільшується за наявності иелюлози. За допомогою скануючої електронної мікроскопї доведено, що гідрогель $з$ целюлозою має нерівну поверхню в порівнянні з гідрогелями без неї. Методами рентгено-структурного аналізу та сканувальна калориметрії встановлено, щзо гідрогелі з целюлозою втрачають кристалічність при полімеризації, а полімеризований гідрогель має краму термостабільність, порівняно з необробленим ичелюлозним волокном. Результати Фур'є-спектроскопї свідчать про полімеризачію між поліакриламідом та иеллюлозою, з посиланням на смугу при 1657,99 $\mathrm{cm}^{-1}$, характерної для $\mathrm{N}-\mathrm{H}$. Досліджено здатність гідрогелю з різним вмістом изелюлози до адсорбиії кадмію як функиї рН. Встановлено, щуо максимальну кількість кадмію адсорбує гідрогель з $2 \%$ иелюлози за рН 4. Показано, щзо такий сорбент може бути використаний для видалення йонів $\mathrm{Cd}$ з водного розчину.

Ключові слова: листя олійної пальми, целюлоза, гідрогель, мікрохвилі, кадмій. 